\title{
Editorial
}

Sarah Nicholson, Zanne Domoney-Lyttle*

\section{Women and Gender in the Bible and the Biblical World II: Editorial Introduction}

https://doi.org/10.1515/opth-2020-0188

received November 21, 2021

In 2020, our first issue of "Women and Gender in the Bible and the Biblical World" was published through Open Theology. ${ }^{1}$ In it, we sought to "encourage a multiplicity of voices and a range of responses which might consider a wide variety of themes and topics but which would all connect via a singular focus: that of women and gender in the Bible and the biblical world."2 Our call for papers was broad and fairly unrestricted, and the responses we received made use of the open scope, providing us with a range of topics, themes, and biblical characters which, when read together in the journal issue, presented the reader with an intellectual, spiritual, and political commentary about understanding the role of women, gender, and sexuality in the Bible and in our world. As noted then, we were not disappointed by the response. In fact, submissions kept arriving which we recognised as valuable and much-needed, and so a second issue of our specialist topic was proposed and accepted.

The number of submissions and the range of topics which were proposed to us for both this volume and the volume published in 2020 reflect two things: the first is that the academic community and biblical scholars more particularly recognise the need to read and write about biblical women from intersectional perspectives. The second is that there is a need or desire for a suitable home for such scholarship. This is not a novel idea; indeed the landscape of biblical feminist studies and biblical reception studies in particular has broadened in the past decade to take into account power dynamics prevalent in gender, ${ }^{3}$ sexuality, ${ }^{4}$ ethnicity, ${ }^{5}$ differently abled bodies, ${ }^{6}$ and class-driven structures. However, any scholar working within these areas recognises that the opportunities to present and publish on such topics are either few and far between, or treated as a novelty which reflects the zeitgeist but is not seen to have longevity. Worse still, in a traditional discipline like Biblical Studies, the novelty of working on intersectionality and the Bible is frequently disparaged by being associated with a "woke" or "leftist" crowd, an assessment intended to be insulting since "woke leftist" academics are often accused of weakening the robustness of traditional scholarship with identity politics.

Creating a space for intersectional feminist Biblical studies is one of the key aims of this special issue. Themes within include postcolonialism, power dynamics and authority, trauma, biblical afterlives and

1 Nicholson and Domoney-Lyttle, "Women and Gender in the Bible."

2 Ibid., 707.

3 For example, see: Henderson-Merrygold, Gender Diversity in the Ancestral Narratives; and JIBS, "The Bible."

4 For example, see: Sherwood and Fisk, The Bible and Feminism, especially: "Part II: An Unconventional Tour of the Biblical Canon;" Greenough, "Queer Theory and the Bible."

5 For example, see: Junior, Reimagining Hagar; and Newton, Identifying Roots.

6 For example, see: Moss, Disability Studies and Biblical Literature.

\footnotetext{
* Corresponding author: Zanne Domoney-Lyttle, Department of Theology and Religious Studies, University of Glasgow, Glasgow, Scotland, United Kingdom, e-mail: Zanne.Domoney-Lyttle@glasgow.ac.uk

Sarah Nicholson: Department of Theology and Religious Studies, University of Glasgow, Glasgow, Scotland, United Kingdom, e-mail: sarah.nicholson@glasgow.ac.uk
} 
reception, maternity and motherhood, and representation more broadly. Siam Hatzaw offers a lucid analysis of the double-colonisation experienced by Asian women in diaspora, by reading Esther intersectionally as a postcolonial feminist icon in order to point to liberative ways of reading the biblical story. She draws attention to the tendency of white Western feminist scholars to celebrate Vashti's defiant refusal of the male gaze, in which perhaps they find their own desires for refusal mirrored. In comparison Esther has been found wanting. However, drawing on the work of Kwok Pui-lan and Musa Dube, Hatzaw critiques the limitations of this white Western feminist framework for understanding Esther's situation as a doubly marginalised woman living in diaspora. She reads Esther through her own experiences as an Asian woman living in the UK, developing an interpretation that invokes Bhabha's concepts of mimicry and hybridity to explore Esther's liminal status, and her depiction as an object of inappropriate projections akin to the expectations of the "model minority," "good migrant," and fetishised "robot geisha." Exposing these projections allows Hatzaw to understand Esther's potential for revolution. While Esther adopts a dual identity - changing her name, assimilating into the Persian court, and "passing" to find favour - her cultural hybridity makes her a "good migrant" subject to a glass ceiling. Her only power is the effect of her sexualisation, which becomes her opportunity to exercise agency. By performing femininity in the context of systemic sexual exploitation, Esther occupies a "Third Space" (Bhabha) in which her commodified body becomes a source of power. Hatzaw argues that Esther "can simultaneously be a victim of sexual exploitation and an autonomous character who chooses to wield her sexuality to gain power over the enemy." Thus the experience of living in diaspora involves displacement and liminality, and yet offers opportunities to identify avenues of resistance that may be invisible to the "host" majorities. Esther's victory comes precisely through her liminality, offering an example of the potential of liberation to Asian diasporic women.

Sorrel Wood also engages avenues of resistance in Esther: in this case Esther's writing. Esther is one of only two women to write in the narratives of the Hebrew Bible (the other is Jezebel). As Esther is a text that constantly "draws attention to its textuality" 8 through the use of letters and written legal materials, the significance and power of textuality is established, while its limits are simultaneously challenged. Drawing on Barthes and Derrida, Wood shows that King Ahasuerus manifests an authorial void: his instability points to the instability of Jewish life in the diaspora, and to a divine absence that contrasts with a pre-exilic divine presence. The king's edicts are oppressive, starting with the oppression of women in Esther 1:20 and 2:8, and so the connections between text, gender, and power are tangled together. In this context, Esther's writing is a "refusal to be focalised through an androcentric narrative": 9 she claims authorial subjectivity, but this is not unproblematic because appropriation of the phallus (pen) is a symbolic death: it signifies absence and deferral. Thus Esther's transgression renders her monstrous. Wood traces accounts of women writing in the ancient world from the second millennium BCE to the second century CE and finds that Esther shares with other women a role of "female intermediary" in which writing is an exercise of "soft power" in men's political structures. Of particular interest is the intertextual connection with Jezebel which, Wood argues, is a deliberate invoking of the Deuteronomistic History to draw attention to the differences between Jezebel's monarchic context, surrounded by accounts of God's presence, and the experience of diaspora, where God is absent from the text and survival necessitates compromise. In Esther's reception she becomes a prophetic figure but in the process loses her agency and the sense of the ambivalence of life in diaspora. Her writing is an attempt at agency but also a sacrifice.

Also intertextually related to Esther is the appearance of Judith in 1 Clement: the first Christian author to cite Judith. Janelle Peters notes that these two women, along with Susanna, are mobilised to support women's leadership, specifically for Queen Shelamzion Alexandra. ${ }^{10}$ While the dating and authorship of Judith are interpreted in various ways, it nevertheless provides a typological account of continuity with Jewish pre-exilic historiography, for ideological purposes. The exclusion of Judith (and Esther) from

7 Hatzaw, "Reading Esther," 29.

8 Wood, "Writing Esther," 37.

9 Ibid., 41.

10 Peters, "Judith and the Elders," 60-8. 
Qumran points to their association with the Hasmoneans, supported by the Pharisees. The trope of the heroic woman lends itself to 1 Clement's discussion of scriptural heroism: Judith is a role model whose courage and humility are praised and compared to Moses' leadership. Her encounter with the elders of her city differs from its scriptural precedent, perhaps because the author of 1 Clement wishes to influence the congregation of the church in Corinth to restore their deposed presbyters, but Judith is presented as an example both to men and to women. Peters thus offers an intriguing account of Judith's reception as a hero and a leader in the early church.

Like Esther and Judith, the daughters of Lot in Genesis 19 may be understood as heroic, if one reads their exercise of agency as a solution to (their perception of) the end of the world. Understanding their agency is a key question in Kirsi Cobb's article. She reads the daughters' narrative through the lens of trauma theory in which Lot's moral failure as a father who presents them to be assaulted by an angry mob is compounded by the loss of the women's mother, exacerbating their trauma. Cobb explores the biology of traumatic memory to suggest that the daughters' visit to Zoar may have been eradicated due to traumatic amnesia, reinforcing the notion of living at the end of the world, and suggesting the solution of incest as reasonable in the circumstances - which include the possibility of their agency as trauma re-enactment. Evaluating the actions of victims of insidious trauma presents difficulties for readers, who may struggle to understand their ethical ambiguities. Building on the work of Juliana Claassens, and reading intertextually with the television adaptations of Margaret Attwood's work, Cobb explores the difficulties in assessing culpability that emerge in responses to the characters Emily and Moria (The Handmaid's Tale) and Grace (Alias Grace). But unlike Moira and Emily, Lot's daughters act to continue their father's line rather than acting against his interests. This, to Cobb, suggests that "obsession with the patriarchal line is ultimately a doomed effort."11

Kitty Bouwman considers biblical divine motherhood in the form of Wisdom: a hostess and teacher in the Hebrew Bible and in the intertestamental literature. She discusses how Sirach's articulation of Wisdom as mother is picked up by Augustine of Hippo and adapted for his own purposes in his tractates on the Gospel of John, which is particularly revealing in terms of his conflict with the Manicheans. While Sirach symbolises Wisdom as a mother (Sirach 24:18), Augustine incorporates Paul's language of milk and solid food from 1 Corinthians 3:2 to present Wisdom to candidates for baptism as a mother who provides eternal nourishment, in which "milk" conveys grace; the baptismal candidates are not yet ready for the "solid food" of spiritual truth that Mother Wisdom provides to the angels but, like a breastfeeding mother, Wisdom provides suitable spiritual food for her infants. However, Jesus acts as a mediator in presenting milk (grace) to the children (those being initiated into Christianity), and at the Incarnation the eternal nourishment of Mother Wisdom is transformed into grace: a departure from Sirach's conceptualisation of Wisdom. Also transformed is the breastfeeding imagery, which may derive from Augustine's North African cultural context including earlier North African patristic texts, and imagery of a lactating Isis, as well as his own personal experience observing breastfeeding by the mother of his child. Meanwhile, Wisdom Mother's "milk," being available to baptismal candidates, provides an argument against the Manicheans: "the mysteries of faith were accessible to the competents" and not only to the already-initiated..$^{12}$

Janelle Peters' second contribution to this special issue explores Paul's references to angels and creation in his instructions on veiling in 1 Corinthians 11, arguing that his use of Second Temple symbolism reflects his theology of baptismal equality between men and women. Rather than drawing attention to a category of women leaders, or categorising women as married, unmarried etc., Paul uses an idea of the interdependence of men and women, based on the second Genesis creation narrative, to present "a democratized vision of the divine and mortal creation" 13 in which both sexes are able to participate in the divine. The veiling instructions may appear to reinforce a hierarchical gender binary and yet, as Peters notes, the angels in 11:10 point to the interdependence which Paul goes on to assert. Useful comparisons are made

11 Cobb, “Look What They’ve Turned Us Into,” 221.

12 Bouwman, "Mother Wisdom," 246.

13 Peters, "Creation, Angels, and Gender," 255. 
with Philo's account of the monastic Therapeutae who produce an interdependent prophetic body; and with 4QInstruction, in which women are created by angels (and men are created by God). These documents may underlie Paul's use of angels, creation, and interdependence in 1 Corinthians and intersect with his ideas about the body as a temple.

A focus on the body - in this case the maternal body - emerges again in Aireen Andal's article on Marian pregnancy in medieval European iconography. Andal employs a lens of spatiality to explore Mary's body, arguing that visual representations of Mary are inextricably bound up with developments in Mary's theological significance. First, Mary's body is represented as the space in which Christ's transition to humanity takes place in the Incarnation. The unborn Christ is portrayed as a complete human body, suggesting the completion of the story of salvation; and Mary is covered, indicating her virginity. Second, Mary's body (especially her unique womb) is a landmark that connects the birth of Jesus to other covenantal births, as well as a site of the battle with those who critiqued the veneration of Mary. Third, medieval images of Mary represent the liminality of Christ's divinity and humanity, but also the space between reverence and sexualisation, in which Mary's body incorporates both virginity and the eroticism of female genitalia; and also indicating the space between the sacred and the secular. Her body "serves as a space where biblical doctrine takes place." ${ }^{14}$ It is a complex unity that produces theological and ideological discourses and constantly subject to reinterpretation.

Katerina Koci examines accountability in the story of Jephthah's daughter in comparison with Iphigenia, and reading her experience of sacrifice through a lens of "powerful powerlessness" to offer a philosophical-theological understanding of the narrative. She considers Girard's approach to the difference between ancient Greek and Hebrew sacrificial stories, in which the perspective of the latter is that of the victim. In the case of Jephthah's daughter, there is no divine command to sacrifice. Meanwhile, Kierkegaard's assessment of the story misses the significance of the daughter's disapproval of her father, whether or not she knows about the vow. Koci considers the implications for constructions of women's submission and argues that Jephthah's daughter does not simply submit; instead, she accuses her father and holds him accountable. Her response to patriarchal power "breaks the structure" 15 and resists Jephthah's attempt to make her responsible. Nevertheless, the loss of her life is still an atrocity and some of the responsibility for her sacrifice belongs to the author-redactor. Koci calls for "a refutation of the sacrifice of any other"16 and a refusal of aggressive forms of power.

The final piece in this issue, by Elazar Ben-Lulu, uncovers hitherto forgotten or under-examined prayers and liturgical texts from the Jewish tradition which are dedicated to female victims of sexual assault. ${ }^{17}$ Ben-Lulu draws upon qualitative data to show how the reframing of certain words, phrases and references can open such prayers and liturgy to both memorialise women's trauma and create a political call-to-action whereby future use of these resources are deliberately used to rectify historically excluded or silenced discourses about trauma associated with sexual violence. Simple changes such as the use of plural pronouns and verbs, the denouncing of patriarchal violence, and the sanctification of women's bodies enable these texts to be read as powerful and empowering statements and offer a new and important discourse between how we view the relationship between bodies, ritual, and trauma.

Like our 2020 special issue, we intend for this issue to demonstrate that there are alternative ways of “doing” Biblical scholarship which better serve underrepresented communities. By creating an open call for our topic of Women and Gender in the Bible and the Biblical World, we have deliberately resisted the idea that collections of academic work such as this one must be unilaterally focused in order to provide a coherent - or cohesive - argument. Instead, this collection is an example of the commonalities found across all of the different subdisciplines which make up Biblical Studies, and it is openness, collaboration, and community which have made this possible. Like our 2020 special issue, this issue is an intellectual,

14 Andal, "The Maternal Body as Space," 266.

15 Koci, "Whose Story?," 339.

16 Ibid., 342.

17 Ben-Lulu, “Teach Your Daughters,” 631. 
spiritual, and political exercise which challenges the status quo of heteronormative and cisgendered readings of the Bible, and aims to provide at least some of the tools to dismantle such hierarchical and oppressive systems which underpin our societies.

\section{References}

Andal, Aireen Grace. "The Maternal Body as a Space: Examining the Visuality of Marian Pregnancy in Late Medieval Europe." Open Theology 7:1 (2021), 256-70.

Ben-Lulu, Elazar. “'Teach Your Daughters to Wail and One Another to Lament': Jewish Prayers and Liturgical Texts for Female Victims of Sexual Assault." Open Theology 7:1 (2021), 631-53.

Blyth, Caroline (eds.). “The Bible: Transgender and Genderqueer Perspectives.” Journal for Interdisciplinary Biblical Studies 1:2 (2020), 1-112.

Bouwman, Kitty. "The Influence of Mother Wisdom on Augustine." Open Theology 7:1 (2021), 238-47.

Cobb, Kirsi. “'Look at What They've Turned Us Into': Reading the Story of Lot's Daughters with Trauma Theory and The Handmaid's Tale.” Open Theology 7:1 (2021), 208-23.

Greenough, Chris (eds.). "Queer Theory and the Bible." Journal for Interdisciplinary Biblical Studies 2:2 (2021), 1-168.

Hatzaw, Ciin Sian Siam. "Reading Esther as a Postcolonial Feminist Icon for Asian Women in Diaspora.” Open Theology 7:1 (2021), 001-034.

Henderson-Merrygold, Jo. Gender Diversity in the Ancestral Narratives: Encountering Sarah \& Esau through a Hermeneutics of Suspicion. PhD Dissertation. University of Sheffield, 2021.

Koci, Katerina. "Whose Story? Which Sacrifice? On the Story of Jephthah's Daughter." Open Theology 7:1 (2021), 331-44. Junior, Nyasha. Reimagining Hagar: Blackness and Bible. Oxford: Oxford University Press, 2019.

Junior, Nyasaha, and Jeremy Schipper. Black Samson: The Untold Story of an American Icon. Oxford: Oxford University Press, 2020.

Moss, Candida, and Jeremy Schipper. Disability Studies and Biblical Literature. London: Palgrave Macmillan, 2011. Newton Jr., Richard W. Identifying Roots: Alex Haley and the Anthropology of Scriptures. Sheffield: Equinox, 2020.

Nicholson, Sarah and Zanne Domoney-Lyttle. "Women and Gender in the Bible and the Biblical World: Editorial Introduction." Open Theology 6:1 (2020), 706-10.

Peters, Janelle. "Creation, Angels, and Gender in Paul, Philo, and the Dead Sea Scrolls." Open Theology 7:1 (2021), $248-55$. Peters, Janelle. "Judith and the Elders of 1 Clement." Open Theology 7:1 (2021), 60-8.

Sherwood, Yvonne and Anna Fisk (eds.). The Bible and Feminism: Remapping the Field. Oxford: Oxford University Press, 2017. Wood, Sorrel. "Writing Esther: How do Writing, Power and Gender Intersect in the Megillah and its Literary Afterlife?" Open Theology 7:1 (2021), 35-59. 